\title{
Learning Sources and Methods Used by Famous Entrepreneurs: A Comparative Study about Three Entrepreneurs from Iran, Japan and United States of America
}

\author{
Ghanbar Mohammadi Elyasi ${ }^{1}$, Fatemeh Sadat Ghafourian ${ }^{1}$ \& Maliheh Faramarzi ${ }^{1}$ \\ ${ }^{1}$ Faculty of Entrepreneurship, University of Tehran, Tehran, Iran \\ Correspondence: Ghanbar Mohammadi Elyasi, Faculty of Entrepreneurship, University of Tehran, Tehran, Iran. \\ Tel: 98-21-8833-9097. E-mail: elyasi@ut.ac.ir
}

Received: June 2, 2012

Accepted: July 3, 2012 Online Published: August 8, 2012

doi:10.5539/ibr.v5n9p60

URL: http://dx.doi.org/10.5539/ibr.v5n9p60

\begin{abstract}
Entrepreneurial perspective emphasizes on idea generation and putting them into action or creation of business. Learning methods used by entrepreneurs have a crucial impact on their capabilities. Entrepreneurs use various sources and methods of learning to achieve the expected capabilities. The main question of this article is: Which sources and methods of learning are mostly used by famous entrepreneurs? Do entrepreneurs who live in different countries use similar learning sources and methods? This research is aimed to examine Kuratko's framework and has added a source and some methods. This framework contains four main sources of learning: "Publications", "Observation", "Speeches and Presentation" and "doing business activities". Content Analysis of documents is used as the research method, which is done by reviewing reliable documents on the three famous entrepreneurs. Amir Kabir, Matsushita and Welch respectively from Iran, Japan and America are selected as research sample. The logic and the reason of our selection are based on their influence in business. Results show that top entrepreneurs learn mostly from informal learning methods including: doing activities, duties, observations and conversations or dialogues, although there are differences for each of the chosen entrepreneurs dependent on his environment. It seems that entrepreneurs select their own sources and learning methods based on contingency approach. Authors suggest that the sources and methods of learning used by top entrepreneurs should be identified and used at universities as formal educational sources. In other words, informal learning sources and methods are recommended for simulation in schools of entrepreneurship.
\end{abstract}

Keywords: learning, entrepreneurship, entrepreneurial learning, learning methods and sources

\section{Introduction}

Entrepreneurial learning has always been an important field of research and, particularly in applied science it has been discussed in order to educate early-stage entrepreneurs, scientifically. Despite all these considerations, there is no clear answer to how it happens and to its different dimensions (Rae, 2005; Cope, 2005). Entrepreneurial learning has direct impact on the quality of action, as Minniti and Bygrave (2001) believe that entrepreneurship is the process of learning and ideas about entrepreneurship should identify their position on how entrepreneurs do the learning (Minniti \& Bygrave, 2001). Timmons (1999) points out that entrepreneurship is a way of thinking and practice with a holistic view which is based on opportunity. Entrepreneurship leads to creation, improvement and recreation of value for owners and stakeholders. In other words, entrepreneurship is the process of dreams and putting them into action (Kuratko, 2005). Entrepreneurship is discussed as a hidden and silent economic revolution which has a definite role in business creation and the gains originated from businesses. Authors believe universities and educational institutions around the world are trying to change entrepreneurship from individual-experimental efforts made by a few practitioners to a scientific, general skill for individuals, organizations, ethnicities, industries, regions, different genders and ages. But the key issue is to find out: how do empirical entrepreneurs learn entrepreneurial actions? Have they learned dreaming and turning it into action via formal education or through informal methods, mainly originated from work and social interactions (Rae, 2005)? Authors believe that universities and educational institutions active in entrepreneurship should at least try to identify learning methods utilized by top entrepreneurial practitioners and simulate them in college and educational environments to train young and emerging entrepreneurs. Sad to sad, this important issue 
has not been extensively contemplated in the Iranian educational environment related to entrepreneurship. With a view to the main concern here, the following research question comes up:

"What methods of learning have been used by top entrepreneurs, who are influential at the national level, in their entrepreneurial activities?”

Some viewpoints about the methods of learning are mentioned first, and then Kuratko's framework (2005), by its extensions; several specific countries have been used to detect learning techniques used by top entrepreneurs.

\section{Literature Review}

Learning plays a vital role in entrepreneur's success. Successful learning leads to the gain of skills, knowledge and abilities required in different stages of business development. So, Learning is a base for the development of entrepreneurship (Wing Yan Man, 2006).

Learning ability is a key component to boost one's entrepreneurship capabilities. Scholars have different views on sources and methods of entrepreneurial learning. Three major sources of learning are suggested in psychology and organization theory: “(a) learning by repetition of efficient practices ("learning by doing”), (b) memorizing new information as a result of training or tutoring, and (c) replacement of incorrect knowledge and practices with new ones based on negative feedback" (Petkova, 2008).

\subsection{Sources and Methods of Learning}

Mulder and his colleagues (2007) studied the learning activities of entrepreneurs. His research was accomplished in Netherlands and capabilities and traits of entrepreneurs were listed and sorted by importance. Ten top small business owners participated in a self-assessment and an assessment by employees as well as external consultants. They found 99 learning activities happening during the innovation process. Reflection, observation and experimentation were the top ones which account for nearly half of the learning activities mentioned in the research. Surprisingly, acquiring knowledge in training, replication and holding on to a personal vision are the least frequent activities and they accounted for only 10 percent of the total learning activities.

Reflection, observation and experimentation, are linked to the three major activities regarding the implementation of innovations: observing what is going on in the environment, experimenting with new initiatives such as firm expansion, observing the results, and reflecting on these results to see what was and was not successful (Mulder et al., 2007).

Petkova (2008) emphasizes that performance errors are regarded as another learning method. Errors and mistakes are implicitly unexpected results in entrepreneurship process. "Learning by doing" encompasses activity as trial and error, explicit problem solving and discovery. This reflects the importance of experience as a central consideration of learning (Cope, 2005). Usually wise entrepreneurs try to learn from their mistakes and errors. Scholars pointed out that, "before individuals can learn from their errors, they have to recognize errors, understand why errors are errors, compare errors to correct actions, and update knowledge structures accordingly" (Stiso \& Payne, 2004; Petkova, 2008). One of the salient treasures of entrepreneurs is to discover many of errors and make an attempt to correct them. This approach is a valuable learning method towards entrepreneurs' success (Petkova, 2008).

Petkova follows this question: “How can entrepreneurs learn from their own performance errors?” He develops a model of entrepreneurial learning from performance errors, and explains how entrepreneurs generate outcomes, and detect and correct flaws in creating and operating a new venture. The model extends psychology models of error-based learning.

Petkova's suggesting model incorporates the major cognitive processes that lead to error detection and error correction. The model is shown in figure 1.

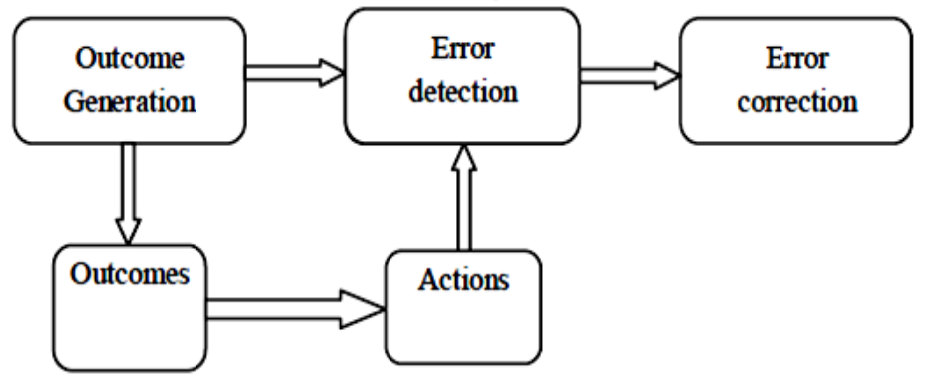

Figure 1. A model of entrepreneurial learning from performance errors (Petkova, 2008) 
Petkova (2008) explains these arguments in specific testable propositions as follows:

- Generation of entrepreneurial outcomes: "According to Jenkins and Johnson (1997), an entrepreneurial outcome represents a desired level of financial performance in the business. More generally, entrepreneurial outcomes could be both tangible, such as organization creation, value creation, innovation, growth, profit, sales, and market share, and intangible, such as entrepreneurs' intrinsic rewards."

- Error detection: "According to Fisher and Lipson (1986), errors reveal the existing cognitive representations of a problem-solving strategy and expose its flaws so that the individuals can understand the cause of error. Thus, it is to the entrepreneurs' advantage to discover as many sources of error as possible, so that they can deepen their knowledge and minimize the number of subsequent errors. The process of error detection involves three steps: observing and interpreting the outcomes, comparing the outcomes to the expectations, and detecting an error."

- Error correction: "Error correction refers to removing flaws from the underlying knowledge structures in order to improve future actions. Error correction consists of three cognitive processes: blame assignment, attribution of bad outcomes, and revision of faulty knowledge structures”. (Petkova, 2008).

David Rae (2005) has been answered the important question in the field of entrepreneurial learning: how do entrepreneurs learn the entrepreneurial ways and activities? He used the thematic discourse analysis covering of three entrepreneurs' stories. He found out that entrepreneurs learn from different and several methods including: early life and family experiences, education and career formation, and social relationships, participation in community, industry and other networks relating to individual experiences, creating business venture through negotiated relationships with others. His research shows that entrepreneurial learning is an outcome of an interactive process between different methods mentioned above (Rae, 2005).

According to three main categories, Rae has identified and discussed eleven sub categories associated with the main categories. The proposed framework's main categories and sub-proposed framework are discussed bellow.

- Personal and social emergence: "Personal and social emergence is the development of entrepreneurial identity, including early life and family experiences, education and career formation, and social relationships. It includes the formation of a sense of self and of future aspirations. In becoming recognized as an enterprising person, people seek to renegotiate their personal and social identities which express who they are, who they want to be, and how they prefer to be recognized within their social context."

- Contextual learning: "Contextual learning occurs through participation in community, industry and other networks in which individual experiences are related, compared and shared meaning is constructed. Through these situated experiences and relationships people can develop intuition and the ability to recognize opportunities. Such learning connects personal emergence with the negotiation of the enterprise, as people learn in their social context "who they can become" and "how to work with others to achieve their ends" as well as the realism of "what can and cannot be"."

- The negotiated enterprise: "The concept of the negotiated enterprise is that the business venture is not enacted by one person alone, but through negotiated relationships with others. The ideas and aspirations of individuals are realized through interactive processes of exchange with others within and around the enterprise, including customers, investors and co-actors such as partners or employees."

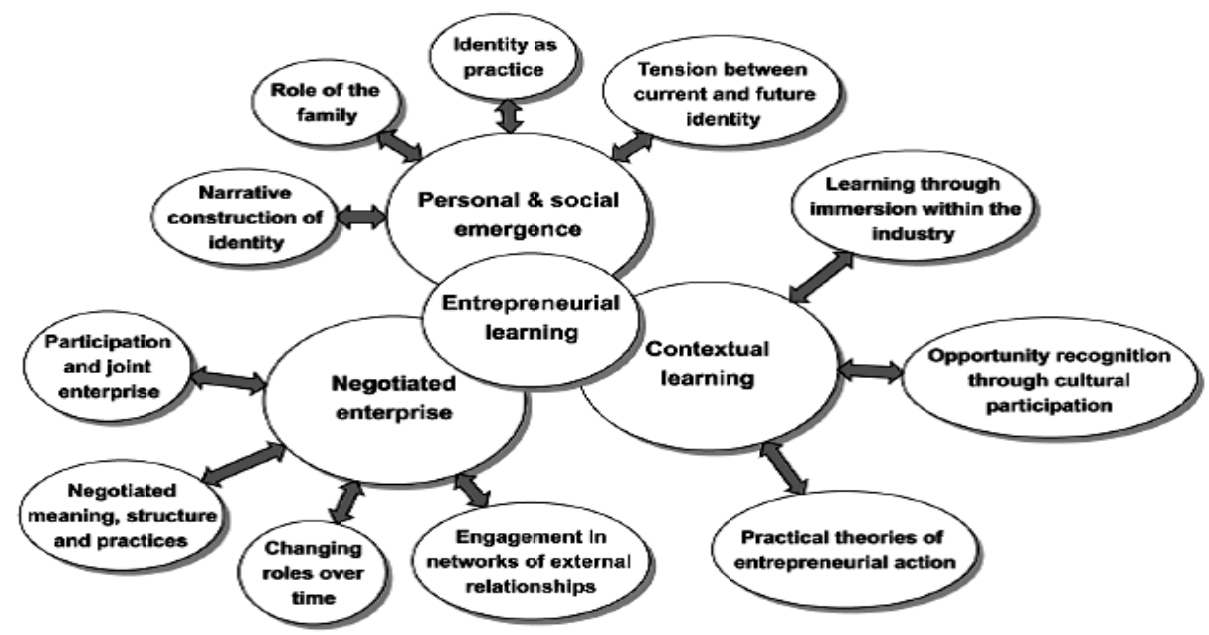

Figure 2. Conceptual model for entrepreneurial learning by David Rae (2005) 
Kuratko (2005) implicitly pointed out that there are three major sources of learning: popular publication, direct observation of practicing entrepreneurs and presentations-speeches by practicing entrepreneurs. He categorized different learning methods based on each source including:

- Popular publication: Academic journals ,textbooks on entrepreneurship, books on entrepreneurship, biographies or autobiographies of entrepreneurs, compendiums about entrepreneurs, news periodicals, venture periodicals, newsletters, proceedings of conferences, government publications;

- Direct observation: interviews, surveys, case studies, and the experiences of individual entrepreneurs can be related;

- Presentations-speeches: seminars "it does provide an opportunity to learn about entrepreneurial perspective" (Kuratko, 2005: 580).

A valuable point in Kuratko's framework (2005) about entrepreneurial learning is that it has paid attention simultaneously to sources and methods of learning for keen entrepreneurs. We have extended this view by adding another source, called Learning by doing which is used by famous entrepreneurs. Here our view goes far beyond that of Kuratko's categorization. We have used other valuable researches to complete the methods appropriate to the four sources. Kuratko's extended framework is shown in figure 3.

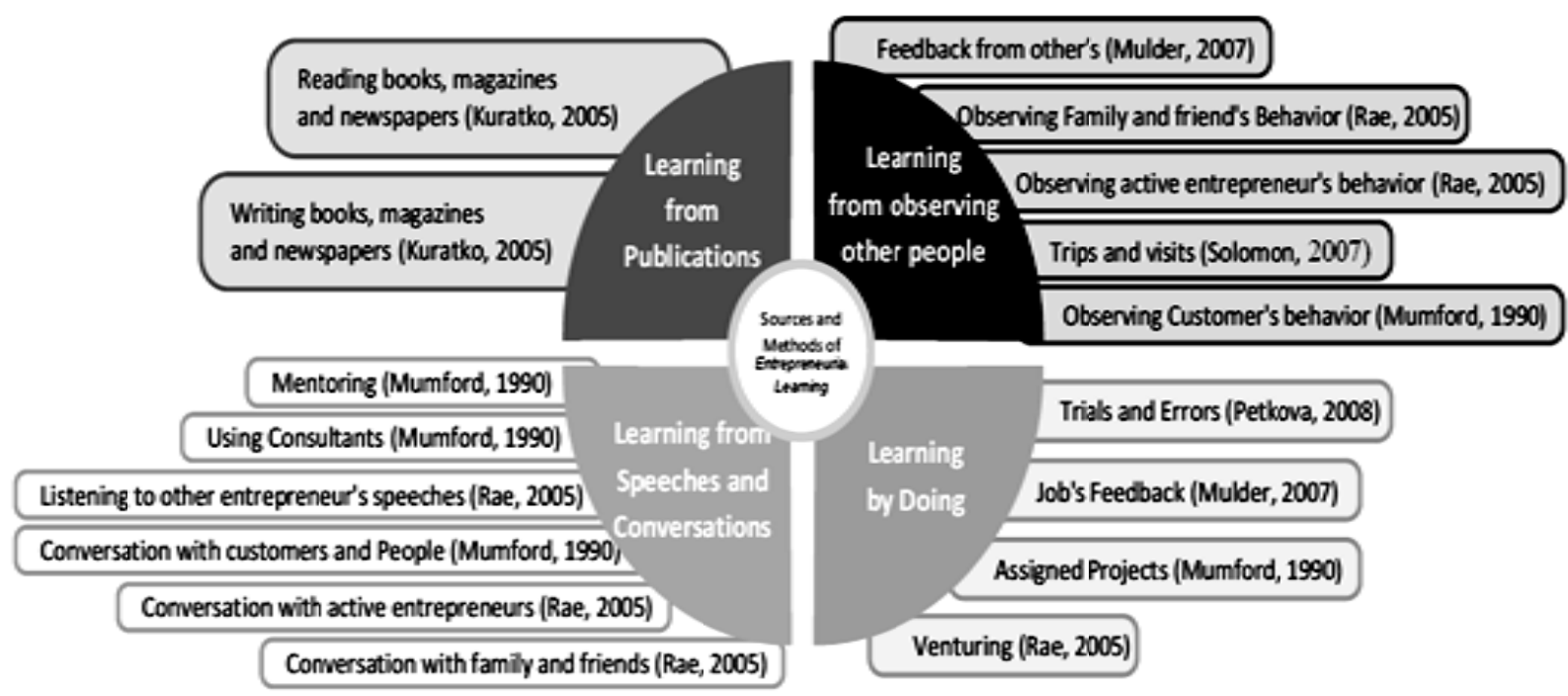

Figure 3. Kuratko’s extended framework

\section{Methodology}

This research is based on three cases, which are dead or unreachable. So, documents analysis or biography analysis of the three famous entrepreneurs selected as research methodology. There are disadvantages to this, like lack of information in some cases, because not everything is mentioned in books. Sure interviews could cover this up, if possible. But also has the strength of being in touch and countable and revisable for any other researcher with a different approach.

Analytical steps are taken, as Bazargan et al. (2010), have modeled. Steps are as follows:

\subsection{Selection of Cases}

In order to cover almost all the learning methods, cases are selected with high variety in different aspects. These cases are different by activation era, environment/culture and even entrepreneurial aspects. We selected three famous entrepreneurs and reliable documents about their lives. Mirza Taqi Khan Amir Kabir (ca. 1806-1852) was the greatest prime minister of the Qajar dynasty. In just 3 years he accomplished more than the combined efforts of the other chief ministers of the dynasty and laid the foundation of modernization in Iran. Amir Kabir built factories, facilitated the commercial activities, and established the first modern institution of learning (Dar al-fonoon institute), employed teachers and technicians from Europe, inaugurated a modern postal system, set up a translation bureau and the modern press, founded the first newspaper, reorganized the judicial system, and prevented the clergies from interfering with the government's jobs. 
Konosuke Matshushita is the Founder of Panasonic. Konosuke was born in 1894, in a poor Japanese family. He began working for himself in 1918 when he actually had nothing: no money, no formal education, and no relations. But, his small firm flourished by the leadership of a smart, wise entrepreneur and finally placed Matsushita's company on the map in the Japanese's electrical manufacturing and retail industry. In 1929, Matsushita began setting up a new structure for his company. The company was structured as a parent company and branches of divisions that specialized in a particular product were created. He used new organization and management methods and suggested divisional system as an innovation. He also founded the "Matsushita institute of government and management”. He invented battery-powered bicycle lamps, light sockets earlier and produced them in his own company. He had innovations in marketing, selling and production process.

Jack Welch, a native of Salem, Massachusetts, served as Chairman and Chief Executive Officer of General Electric (GE) from 1981-2001. He received his B.S. degree in chemical engineering from the University of Massachusetts in 1957 and his M.S. and Ph.D. degrees in chemical engineering from the University of Illinois in 1960. He began his career with the General Electric Company in 1960, and in 1981 became the Company's 8th Chairman.

During his 20 years of leadership in this position, Welch increased the value of the company from $\$ 13$ billion to several hundred billion. His management system was his innovation which was so different from bureaucracy. Managers were given free reign as long as they followed the GE ethic of constant change and striving to do better He ran GE like a small dynamic business able to change as opportunities arose or when a business became unprofitable. Through streamlining operations, acquiring new businesses, and ensuring that each business under the GE umbrella was one of the best in its field the company was able to expand dramatically from 1981 to 2001 . He used 6sigma in 1995 successfully.

"Amir Kabir and Iran” is the most reliable reference on Amir Kabir's biography and has been used in this research as the main reference. About Matsushita's life there are considerable numbers of books written. "Matsushita Leadership", which is a work of Harvard University's research team, is selected as a reference together with other books of Matsushita, himself. "Jack: Straight from the Gut” is a book written by Jack Welch and surely is a reliable reference on his life. All the references used in this section are listed in table 1.

Table 1. Documents used to analyze stories

\begin{tabular}{lllll}
\hline & Document & Entrepreneur & Publishing year & author \\
\hline 1 & Amir Kabir and Iran & Amir Kabir & 1967 & Adamiat, Fereydun \\
2 & Amir Kabir or the Hero of Battle with Colonialism & Amir Kabir & 1965 & Hashemi Rafsanjani, Akbar \\
3 & Matsushita Leadership & Matsushita & 1997 & Kotter, John P. \\
4 & Quest for Prosperity & Matsushita & 1998 & Matsushita, Konosuke \\
5 & Jack: Straight from the Gut & Jack Welch & 2001 & Welch, Jack, Byrne, John A. \\
\hline
\end{tabular}

\subsection{Goals and Questions}

The main goal of this research is to realize the sources and methods of learning which are mostly used by famous entrepreneurs. The question posed in this research is: Which sources and methods of learning had Amir Kabir, Matsushita and Welch used? In other words, do famous entrepreneurs use similar sources and methods of learning in different countries?

\subsection{Criteria Definition}

We have extended Kuratko's framework to analyze the events related to learning mentioned in reliable documents. Considering this Framework, learning has four sources including: publications, observations, speech-conversation, and learning by doing. Special methods are defined for each source as the framework is explained in the literature review section.

\subsection{Unit of Analysis}

Stories and events are the units of analysis. Events or stories are recorded if there exists clues and evidences of learning in them. In this step, we have reviewed all the given references to find the events and stories related to entrepreneurs' learning. Events and stories are analyzed based on Kuratko's extended framework.

\subsection{Categorization}

Each dimension of the Kuratko's extended framework is considered as a category in the research. 


\subsection{Analysis Technique}

Quantitative analysis is done using descriptive statistics (frequencies).

\section{Findings}

In order to detect and extract stories and events related to entrepreneurial learning, the most reliable biographies and books were chosen and reviewed. The chosen stories and events are recognized and categorized. Table 2 lists some examples of the process of recognizing the entrepreneurial learning methods from the stories and events which are extracted from the entrepreneurs' lives.

Table 2. Samples of events and stories

\begin{tabular}{|c|c|c|c|}
\hline \multirow[t]{2}{*}{ Entrepreneurs } & \multirow[t]{2}{*}{ The events and stories } & \multicolumn{2}{|l|}{ Learning } \\
\hline & & Method & Source \\
\hline Matsushita & $\begin{array}{l}\text { In 1927, Matsushita selected an employee as the manager of the whole process of } \\
\text { electric heater. This was so useful. Expanding one's authorities made the } \\
\text { manager act as an entrepreneur and grow. Independency and being apart from the } \\
\text { whole organization nurtured employees' creativity and tendency for work. } \\
\text { Therefore, Matsushita announced segmentation system in } 1933 \text { (Kotter, 1997: } \\
\text { 107). }\end{array}$ & Trial and error & $\begin{array}{l}\text { Learning by } \\
\text { doing }\end{array}$ \\
\hline Amir Kabir & $\begin{array}{l}\text { Amir Kabir's missionary trip to Russia when he was still young was so instructive. } \\
\text { There he showed his well manner to Amir Nezam Zangene, and in return he got a } \\
\text { job in the government (Adamiat, 1967: 60). He visited academies in Russia and he } \\
\text { established Dar-al fonoon institute right after he became the great minister. The } \\
\text { same happened about industry, which led to the building of many factories } \\
\text { (Adamiat, 1967: 353). }\end{array}$ & $\begin{array}{l}\text { Trips and visits } \\
\text { Conversation } \\
\text { with customers } \\
\text { and People }\end{array}$ & $\begin{array}{l}\text { Observations } \\
\text { Speeches and } \\
\text { Conversations }\end{array}$ \\
\hline Welch & $\begin{array}{l}\text { Having failed in the final game of hockey, Jack was in the changing room while } \\
\text { his mother came in and said: “You are worthless. You won't learn how to win as } \\
\text { far as you cannot deal with failure. You shouldn't have played.” Grace Welch } \\
\text { thought him his first lesson of contest along just like the pleasure and need of } \\
\text { accepting failure. (Welch and Byrne, 2001:18) }\end{array}$ & $\begin{array}{l}\text { Conversation } \\
\text { with family and } \\
\text { friends }\end{array}$ & $\begin{array}{l}\text { Speeches and } \\
\text { conversations }\end{array}$ \\
\hline
\end{tabular}

Frequency of the stories and events extracted of appointed entrepreneurs' lives, are shown in table 3.

Table 3. Frequencies and percentage of the stories related to entrepreneurial learning

\begin{tabular}{|c|c|c|c|c|c|c|c|c|}
\hline & \multirow{2}{*}{$\begin{array}{l}\text { Learning } \\
\text { Sources }\end{array}$} & \multirow[t]{2}{*}{ Learning Methods } & \multicolumn{2}{|c|}{ Amir Kabir } & \multicolumn{2}{|c|}{ Matsushita } & \multicolumn{2}{|l|}{ Welch } \\
\hline & & & $\begin{array}{l}\text { Method } \\
\text { Freq. } \\
\text { (per.) }\end{array}$ & $\begin{array}{l}\text { Source } \\
\text { freq. } \\
\text { (Per.) }\end{array}$ & $\begin{array}{l}\text { Method } \\
\text { Freq. } \\
\text { (per.) }\end{array}$ & $\begin{array}{l}\text { Source } \\
\text { freq. } \\
\text { (Per.) }\end{array}$ & $\begin{array}{l}\text { Method } \\
\text { Freq. } \\
\text { (per.) }\end{array}$ & $\begin{array}{l}\text { Source } \\
\text { freq. } \\
\text { (Per.) }\end{array}$ \\
\hline \multirow[t]{2}{*}{1} & $\begin{array}{l}\text { Learning } \\
\text { From }\end{array}$ & $\begin{array}{l}\text { Reading books, magazines and } \\
\text { newspapers }\end{array}$ & $2(3 \%)$ & $5(7 \%)$ & $0(0 \%)$ & $0(0 \%)$ & $3(7 \%)$ & $3(7 \%)$ \\
\hline & Publications & $\begin{array}{l}\text { Writing books, magazines and } \\
\text { newspapers }\end{array}$ & $3(4 \%)$ & & $0(0 \%)$ & & $0(0 \%)$ & \\
\hline \multirow[t]{5}{*}{2} & Learning & Feedback from Other's & $7(9 \%)$ & $21(28 \%)$ & $3(7 \%)$ & $17(37 \%)$ & $9(22 \%)$ & $20(49 \%)$ \\
\hline & from & Observing Family and friend's Behavior & $4(5 \%)$ & & $1(2 \%)$ & & $2(5 \%)$ & \\
\hline & observing & Observing active entrepreneur's behavior & $4(5 \%)$ & & $5(11 \%)$ & & $5(12 \%)$ & \\
\hline & other people & Trips and visits & $6(8 \%)$ & & $6(13 \%)$ & & $4(10 \%)$ & \\
\hline & & Observing Customer's behavior & $0(0 \%)$ & & $2(4 \%)$ & & $0(0 \%)$ & \\
\hline \multirow[t]{6}{*}{3} & Learning & Conversation with family and friends & $0(0 \%)$ & $8(11 \%)$ & $0(0 \%)$ & $11(24 \%)$ & $3(7 \%)$ & $5(12 \%)$ \\
\hline & From & Conversation with active entrepreneurs & $3(4 \%)$ & & $2(4 \%)$ & & $0(0 \%)$ & \\
\hline & $\begin{array}{l}\text { Speeches and } \\
\text { Conversations }\end{array}$ & $\begin{array}{l}\text { Listening to other entrepreneur's } \\
\text { speeches }\end{array}$ & $0(0 \%)$ & & $4(9 \%)$ & & $1(2 \%)$ & \\
\hline & & Conversation with customers and People & $1(1 \%)$ & & $2(4 \%)$ & & $0(0 \%)$ & \\
\hline & & Mentoring & $2(3 \%)$ & & $2(4 \%)$ & & $0(0 \%)$ & \\
\hline & & Using Consultants & $2(3 \%)$ & & $1(2 \%)$ & & $1(2 \%)$ & \\
\hline \multirow[t]{4}{*}{4} & Learning $\mathrm{By}$ & Trial and Error & $0(0 \%)$ & $40(54 \%)$ & $7(15 \%)$ & $18(39 \%)$ & $0(0 \%)$ & $13(32 \%)$ \\
\hline & Doing & Job’s Feedback & $6(8 \%)$ & & $2(4 \%)$ & & $9(22 \%)$ & \\
\hline & & Assigned Projects & $28(38 \%)$ & & $7(15 \%)$ & & $4(10 \%)$ & \\
\hline & & Venturing & $6(8 \%)$ & & $2(4 \%)$ & & $0(0 \%)$ & \\
\hline
\end{tabular}




\section{Discussions}

Researchers have extracted stories and events related to entrepreneurial learning. Before starting the analysis phase, we should mention one point: Stories extracted from document, usually don't illustrate the quality and depth of learning, and we have considered the frequency of stories and events in this research, which actually shows the main sources and methods of learning used by the entrepreneur.

Amir Kabir has worked and lived with Qa'em Magham Farahani, in about 29 years of his life. As he was a great man in politics and manner, he sure had an enormous impact on Amir. But as our methodology is based on document analysis, and there were not enough stories or events, mentioning exactly his effects, our results show a very light impact of his.

Findings of this research are shown in the table 3. Base on these findings, learning by doing and observations generally have had a special impact in entrepreneurs' professional life.

Learning from doing is ranked as the first source of learning used by the Matsushita and Amir, while it is ranked as the second source of learning in Welch's professional life. Learning from observation also helps entrepreneurs to find out entrepreneurial ways and activities.

As you can see, among all sources used by these three entrepreneurs, Amir Kabir has the highest frequency of 40 (54\%) stories for learning by doing and then 21 stories for observation 21 (28\%). Matsushita has 18 (39\%) stories for learning by doing and 17 (37\%) for observations. Welch has 20 (49\%) stories about observations and 13 (32\%) stories about doing by learning.

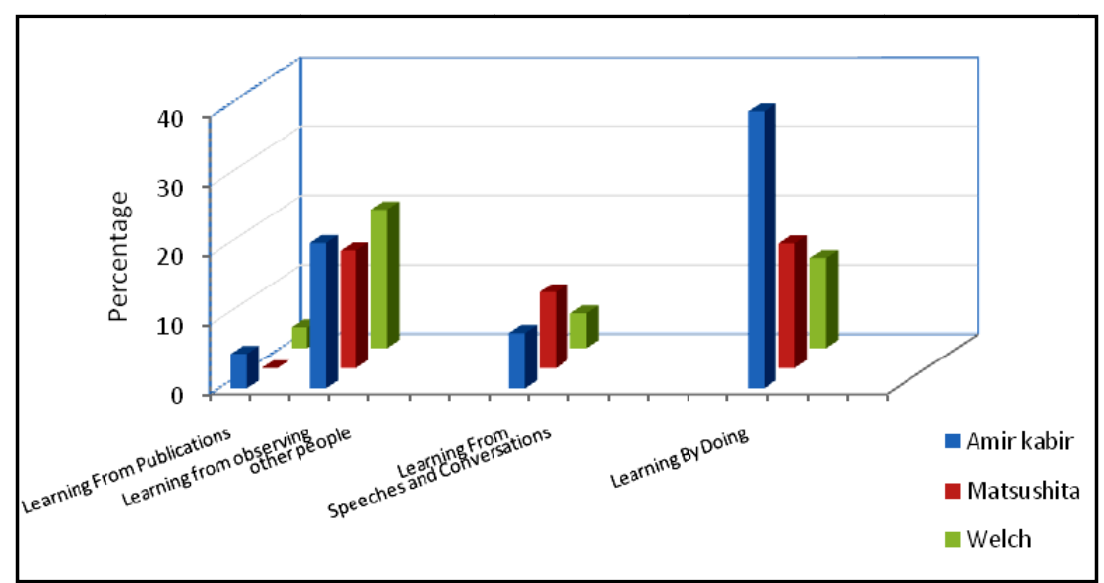

Figure 4. Sources of learning: Comparison between Welch, Amir and Matsushita

Results in Table 3 show differences in methods chosen by the entrepreneurs; Differences are discussed as follows:

Source of Publications: We couldn't find any document on Matsushita using this source, but Amir Kabir has used this source through reading and writing. Welch has studied Draker's through his writings and Amir used to order his employees to translate foreign books and newsletters and even combine them into new books (figure $5)$.

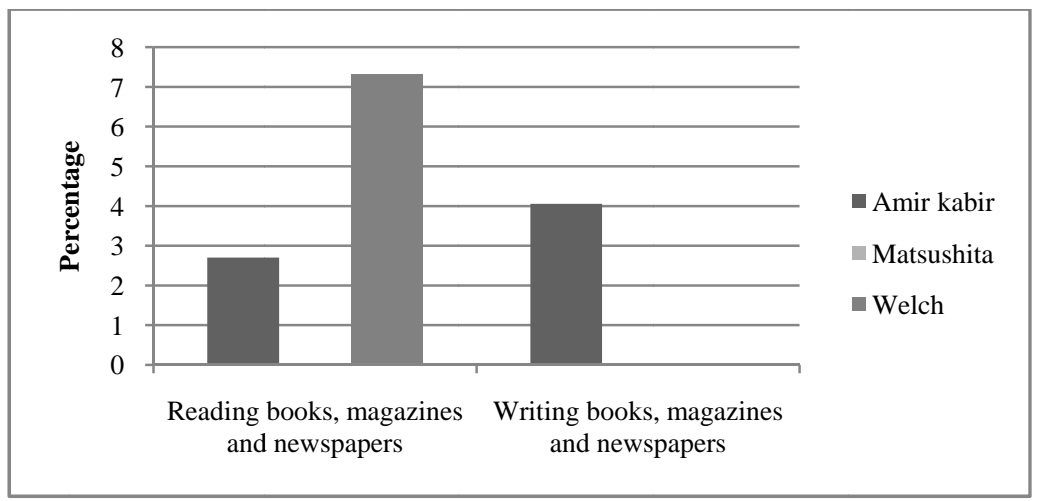

Figure 5. Learning from publication: comparison between Amir Kabir, Welch and Matsushita 
Observation: Amir has used people's feedback and trips as methods of learning. Welch has also mostly learnt through other people's feedbacks, but Matsushita used through trips and visits (figure 6).

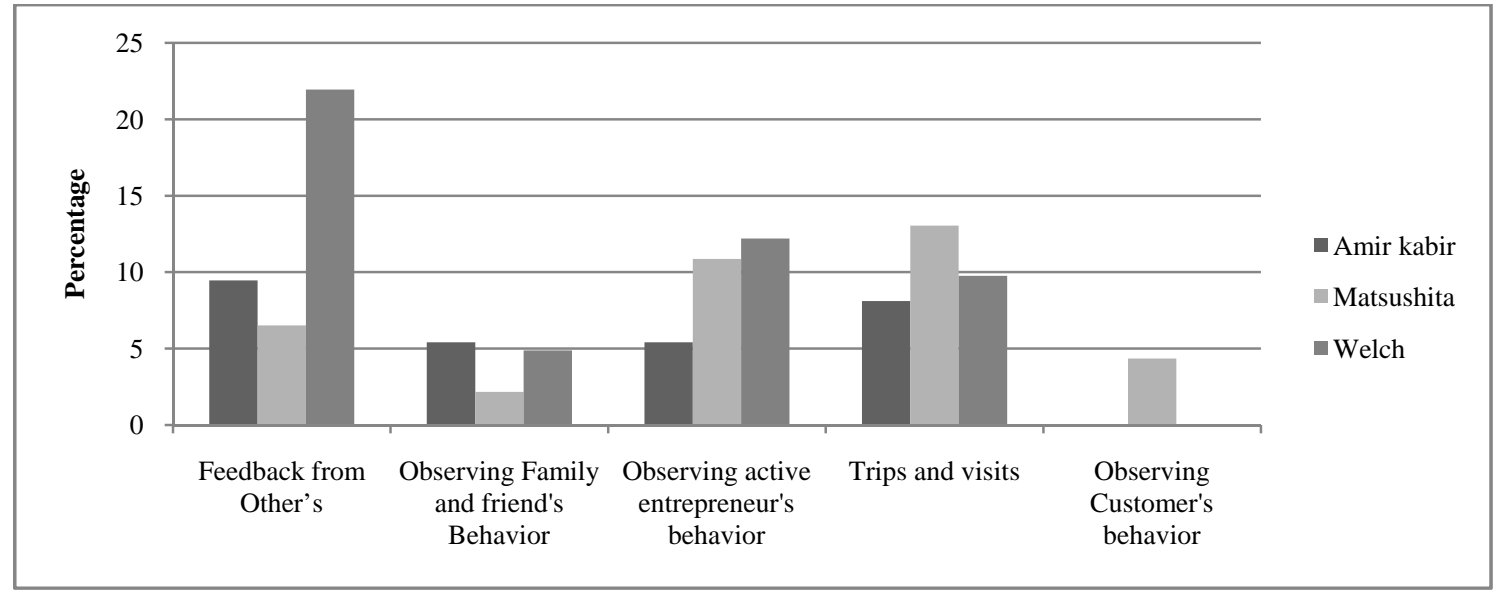

Figure 6. Learning from observations: comparison between Amir Kabir, Welch and Matsushita

Source of Speeches and Conversations: Welch and Amir seem to learn more from having conversations to practicing entrepreneurs, but Matsushita has mentioned listening to speeches as his method of learning (figure 7).

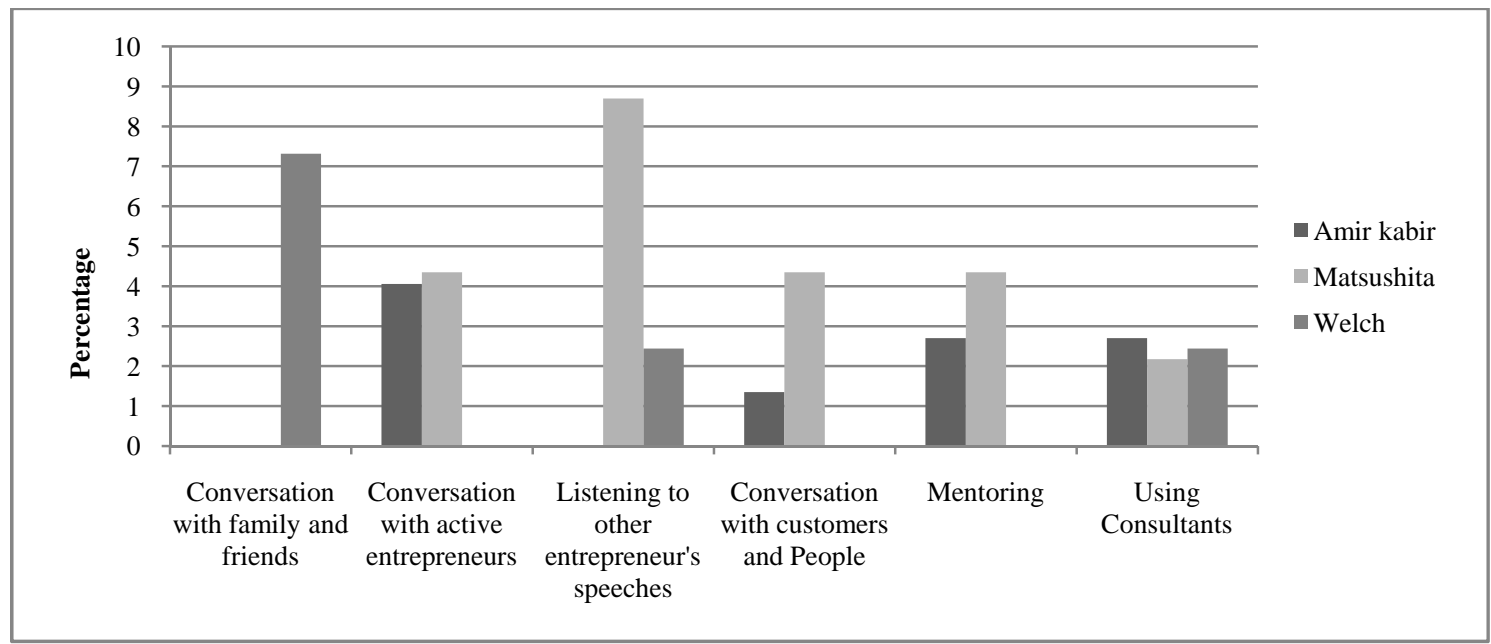

Figure 7. Learning from speech and conversation: comparison between Amir Kabir, Welch and Matsushita

Source of Learning by doing: Amir has mostly learnt through assigned projects, Matsushita has used trials errors and also assigned projects and Welch have used feedback from work (figure 8).

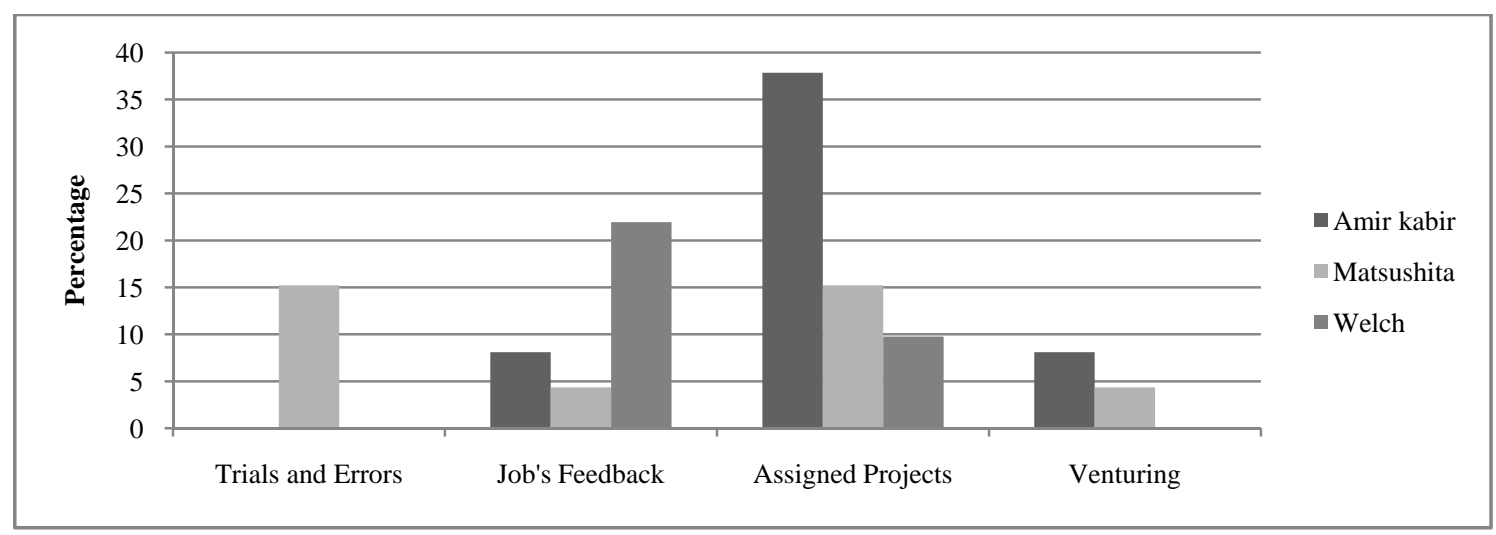

Figure 8. Learning by doing: comparison between Amir Kabir, Welch and Matsushita 
This research supports the results of Mulder's research, which has represented observation, feedback and trials as the main source of learning. In other words Matsushita, Amir Kabir and Welch as three top entrepreneurs have used observation others and learning by doing mostly.

Matsushita has mostly learnt from trials and errors which support Petkova's research (2008) which is based on learning from the errors as an important method of learning. But this doesn't seem to be true about Amir and Welch. A reason for this might be that Matsushita was a business man and a pioneer and these are bound with trials and errors. Amir was a man of politics and has mostly imitated other people in other countries; this helps him more immune to errors. Welch also was a manager and his entrepreneurship was through changes in bureaucracy and business development. Table 4 shows the result of this research compared to the previous researches.

Table 4. Comparison of research findings with previous studies

\begin{tabular}{|c|c|c|}
\hline Author & Finding & Comparison \\
\hline $\begin{array}{l}\text { Rae } \\
(2005)\end{array}$ & $\begin{array}{l}\text { He found out that entrepreneurs learn from different and several } \\
\text { methods including: early life and family experiences, education and } \\
\text { career formation, and social relationships, participation in community, } \\
\text { industry and other networks relating to individual experiences, creating } \\
\text { business venture through negotiated relationships with others. }\end{array}$ & $\begin{array}{l}\text { This research supports the results of Rae's } \\
\text { research, which has represented observation, } \\
\text { conversation and venturing as methods of } \\
\text { learning. }\end{array}$ \\
\hline $\begin{array}{l}\text { Mulder et al. } \\
\text { (2007) }\end{array}$ & $\begin{array}{l}\text { Reflection, observation and experimentation were the top ones which } \\
\text { account for nearly half of the learning activities mentioned in the } \\
\text { research. }\end{array}$ & $\begin{array}{l}\text { This research supports the results of Mulder's } \\
\text { research, which has represented observation, } \\
\text { feedback and trials as the main source of } \\
\text { learning. }\end{array}$ \\
\hline $\begin{array}{l}\text { Petkova } \\
\text { (2008) }\end{array}$ & $\begin{array}{l}\text { Three major sources of learning are suggested in psychology and } \\
\text { organization theory: “(a) learning by repetition of efficient practices } \\
\text { ("learning by doing”), (b) memorizing new information as a result of } \\
\text { training or tutoring, and (c) replacement of incorrect knowledge and } \\
\text { practices with new ones based on negative feedback" }\end{array}$ & $\begin{array}{l}\text { Matsushita has mostly learnt from trials and } \\
\text { errors which support Petkova's research (2008) } \\
\text { which is based on learning from the errors as an } \\
\text { important method of learning. But this doesn't } \\
\text { seem to be true about Amir and Welch. }\end{array}$ \\
\hline
\end{tabular}

\section{Conclusion}

This research illustrates that the top entrepreneurs learn mostly from informal learning methods including: doing activities, duties, observations and conversations or dialogues. However formal educational systems such as learning from education and specialized publications do not have unique impacts on their entrepreneurial ways and activities.

On the other hand the sources and methods of learning for each of the chosen entrepreneurs are almost different and depend on some key factors like individual characteristics, family status and educational system, based on key factors. It appears that entrepreneurs select their own sources and learning methods, the so-called contingency approach. Through contingency view, entrepreneurs should choose sources and learning methods based on some factors mentioned above.

With a view to the findings of this research, we suggest that the sources and methods of learning used by top entrepreneurs should be identified and used at the universities, which are operating entrepreneurial departments or centers as formal educational process. Recent years, visionary universities have shifted towards the entrepreneurial education with the aim of training young generation and nascent entrepreneurs. The universities have paid considerable attention to behavioral simulation as an approach to entrepreneurial education. They are trying to simulate sources and methods of learning which are used by experiential entrepreneurs. In this approach, the informal learning sources and methods are recommended for simulation in schools of entrepreneurship as follows:

1. Learning from observing successful people in various ways such as: visiting industry and successful people's businesses (learning from observation).

2. Learning from speech and dialogue with top entrepreneurs including: using resident entrepreneurs' method, inviting entrepreneurs as guests speakers during the course, hiring entrepreneurs as consultant or mentor at the universities (learning from dialogue).

3. Learning from doing by internship in industry, establishing students' business at universities, idea generation projects and projects of evaluating the idea and opportunities (learning from practical application). 


\section{Limitations}

As it is mentioned in the biography of the selected cases, two of them are dead and one is unreachable, because he lives in U.S. and the research is accomplished in Iran. So we had to learn about their lives through some books. Especially about Amir Kabir, who lived about a century before, when writing books was not so prevalent in Iran, there were not enough references in hand. Sure it was much better if there was an autobiography of Amir, just like Mutsuhito and Welch.

\section{Further Research}

Learning methods vary depending on the social conditions, living era, family and many other things. This research should be done in different contexts, comparing entrepreneurs of a same society, or living in a same era, or even working in similar fields.

This research was qualitative, but a quantitative version of it can examine the proposed model.

\section{References}

Adamiat, F. (1967). Amir Kabir and Iran (9th ed.). Tehran: Khwarizmi Publications.

Carrier, C. (2007). Strategies for teaching entrepreneurship: what else beyond lectures, case studies and business plans (Vol. 1, pp. 143-158). Handbook of research in entrepreneurship education. Edward Elgar Publishing.

Cope, J. (2005). Toward a Dynamic Learning Perspective of Entrepreneurship. Entrepreneurship: Theory and Practice, 29(4), 373-397. http://dx.doi.org/10.1111/j.1540-6520.2005.00090.x

Hashemi Rafsanjani, A. (1965). Amir Kabir or the Hero of Battle with Colonialism (1st ed.). Tehran: Farahani Publications.

Kotter, J. P. (1997). Matsushita Leadership. Tehran: State Management Training Center (in Persian).

Kuratko, D. F. (2005). The Emergence of Entrepreneurship Education: Development, Trends, and Challenges. $\begin{array}{llll}\text { Entrepreneurship: Theory and } & \text { 577-597. }\end{array}$ http://dx.doi.org/10.1111/j.1540-6520.2005.00099.x

Matsushita, K. (1998). Quest for Prosperity. Tehran: Managers Industry Association of Iran (in Persian).

Minniti, M., \& Bygrave, W. (2001). A Dynamic Model of Entrepreneurial Learning. Entrepreneurship: Theory and Practice, 25, 5-16.

Mulder, M., Lans, T., Verstegen, J., Biemans, H., \& Meijer, Y. (2007). Competence development of entrepreneurs in innovative horticulture. Journal of Workplace Learning, 19(1), 32-44. http://dx.doi.org/10.1108/13665620710719330

Mumford, A. (1990). Developing Top Managers. Gower House: Gower Publishing Company Limited.

Petkova, A. P. (2008). A theory of entrepreneurial learning from performance errors. International Entrepreneurship and Management Journal, 5(4), 345-367. http://dx.doi.org/10.1007/s11365-008-0075-2

Rae, D. (2005). Entrepreneurial learning: a narrative-based conceptual model. Journal of Small Business and Enterprise Development, 12(3), 323-335. http://dx.doi.org/10.1108/14626000510612259

Sarmad, Z., Bazargan, A., \& Hejazi, E. (2004). Research Methods in Behavioral Sciences. Tehran: Agahah Institute Publications.

Solomon, G. (2007). An examination of entrepreneurship education in the United States. Enterprise Development, 14(2). 168-182. http://dx.doi.org/10.1108/14626000710746637

Timmons, J. A. (1999). New venture creation: entrepreneurship for the 21st century. Singapore: McGraw-hill co.

Welch, J., \& Byrne, J. A. (2001). Jack: Straight from the Gut. Tehran: Industrial Management Institute (in Persian).

Wing Yan Man, T. (2006). Exploring the behavioral patterns of entrepreneurial learning: a competency approach. Education and Training, 48(5), 309-321. http://dx.doi.org/10.1108/00400910610677027 